\title{
Laryngopharyngeal reflux COPD to uncover reflux and columnar lined esophagus
}

\author{
This article was published in the following Dove Press journal: \\ International Journal of COPD \\ 30 September 2015 \\ Number of times this article has been viewed
}

\section{Ivan Kristo \\ Martin Riegler \\ Sebastian F Schoppmann}

Upper-GI-Service, Gastroesophageal Tumor Unit, Department of Surgery, Comprehensive Cancer Center, Medical University of Vienna, Vienna, Austria
Correspondence: Sebastian F Schoppmann Upper-GI-Service, Gastroesophageal Tumor Unit, Department of Surgery, Comprehensive Cancer Center, Medical University of Vienna, Währinger Gürtel 18-20, I090 Vienna, Austria

Tel +43 | 40400562 I

Fax +43 I 40400564 I

Email sebastian.schoppmann@

meduniwien.ac.at

\section{Dear editor}

With interest we read the article by Jung et $\mathrm{al}^{1}$ published in the recent issue of the International Journal of Chronic Obstructive Pulmonary Disease. An important finding of the study was the positive correlation between symptoms of gastroesophageal reflux disease (GERD), endoscopic signs for laryngopharyngeal reflux (LPR), and COPD. ${ }^{1}$ COPD represents an increasing health burden. ${ }^{2,3}$ Owing to the symptoms, COPD impairs the productivity and life quality of those affected. ${ }^{2,3}$ Frequently, COPD requires chronic administration of cortisone therapy, which itself produces side effects impairing well being. ${ }^{4,5}$ The finding that COPD associates with LPR and GERD opens the trail for additional diagnostic and therapeutic considerations.

If GERD is suspected, one may want to define the amount, characteristics, and components of GERD. Thus, endoscopy and histopathology of esophageal biopsies help to assess the morphologic manifestation of GERD, ie, hiatal hernia, esophagitis, and columnar lined esophagus in the distal or proximal portion of the esophagus. ${ }^{6}$ Presence of Barrett's esophagus defines increased cancer risk and may be managed by surveillance or, in cases of increased cancer risk (dysplasia), by elimination of Barrett's esophagus tissue by endoscopic radiofrequency ablation ( \pm endoscopic mucosal resection). ${ }^{6}$ Furthermore, esophageal manometry and reflux monitoring characterize reflux, that causes symptoms, ie, aggravates COPD and LPR. ${ }^{5,6}$ In summary, the orchestration of diagnostic findings offers the path for a tailored therapy, ie, medical, nutrition or, in cases of advanced GERD, resolution of reflux by laparoscopic anti reflux surgery. ${ }^{5,6}$ Going in line with the considerations of Jung et $\mathrm{al}^{1}$ we think that LPR-positive COPD patients should be offered the above algorithm to attenuate the progression of the disease and the need for cortisone therapy. ${ }^{2,4}$ We kindly ask the authors to address the above suggestions.

\section{Disclosure}

The authors report no conflicts of interest in this communication.

\section{References}

1. Jung YH, Lee DY, Kim DW, et al. Clinical significance of laryngopharyngeal reflux in patients with chronic obstructive pulmonary disease. Int J Chron Obstruct Pulmon Dis. 2015;10:1343-1351.

2. Ajmera M, Raval AD, Shecn C, Sambamoorthi U. Explaining the increased health care expenditures associated with gastroesophageal reflux disease among elderly Medicare beneficiaries with chronic obstructive pulmonary disease: a cost-decomposition analysis. Int J Chron Obstruct Pulmon Dis. 2014;9: 339-348.

3. Landis SH, Muellerova H, Mannino DM, et al. Continuing to Confront COPD International Patient Survey: methods, COPD prevalence, and disease burden in 2012-2013. Int J Chron Obstruct Pulmon Dis. 2014;9:597-611. 
4. Woods JA, Wheeler JS, Finch CK, Pinner NA. Corticosteroids in the treatment of acute exacerbations of chronic obstructive pulmonary disease. Int J Chron Obstruct Pulmon Dis. 2014;9:421-430.

5. Promberger R, Spitzer A, Ott J, et al. Quality of life in type 2 diabetics with gastroesophageal reflux disease: a case control study. Eur Surg. 2013;45:194-199.
6. Subramanian CR, Triadafilopoulos G. Radiofrequency-based treatments for esophageal disease. Eur Surg. 2014;46:12-20.

Dove Medical Press encourages responsible, free and frank academic debate. The content of the International Journal of Chronic Obstructive Pulmonary Disease 'letters to the editor' section does not necessarily represent the views of Dove Medical Press, its officers, agents, employees, related entities or the International Journal of Chronic Obstructive Pulmonary Disease editors. While all reasonable steps have been taken to confirm the content of each letter, Dove Medical Press accepts no liability in respect of the content of any letter, nor is it responsible for the content and accuracy of any letter to the editor.

International Journal of COPD

\section{Publish your work in this journal}

The International Journal of COPD is an international, peer-reviewed journal of therapeutics and pharmacology focusing on concise rapid reporting of clinical studies and reviews in COPD. Special focus is given to the pathophysiological processes underlying the disease, intervention programs, patient focused education, and self management protocols.

Dovepress

Submit your manuscript here: http://www.dovepress.com/international-journal-of-chronic-obstructive-pulmonary-disease-journal

This journal is indexed on PubMed Central, MedLine and CAS. The manuscript management system is completely online and includes a very quick and fair peer-review system, which is all easy to use. Visit $\mathrm{http}: / / \mathrm{www}$.dovepress.com/testimonials.php to read real quotes from published authors. 